\title{
Factors Affecting Information and Communication Technology (ICT) Use by Southern Colleges Teachers in Balqa Applied University
}

\author{
Sami A. Tarawneh, Sattam Allahawiah \\ Balqa Applied University, Jordan \\ taraw.sami@gmail.com \\ Balqa Applied University, Jordan \\ sattam.amro@yahoo.com
}

\section{ABSTRACT}

This research was conducted to study the factors affecting the use of Information and Communication Technologies (ICTs) by Southern Colleges Teachers in Balqa applied university teachers. The results of this study indicate that even though a majority of respondents use ICT in teaching activities. The descriptive results indicated that teachers had high level of knowledge and skill in applying ICT. In addition, computer and internet are available to majority of respondents. It appeared from the findings of this research that technologies are used at the high level. Providing more availability of ICT to teachers as the most producers of the information and knowledge will be essential. The findings of regression analysis also showed that the skill in using ICT explained 3.63 of extent to which faculty members used ICT variance. This result refers to the fact that holding educational courses aiming at increasing people's familiarity and knowledge about ICT will improve the usage of these technologies.

Keywords: ICT, Higher Education, Factors Affecting

\section{Council for Innovative Research}

Peer Review Research Publishing System

Journal: INTERNATIONAL JOURNAL OF COMPUTERS \& TECHNOLOGY

Vol 12, No. 10

editor@cirworld.com

www.cirworld.com, www.ijctonline.com 


\section{INTRODUCTION}

Information Communication Technology is a network which offers a steadily expanding range of new services; it is computer-based tools used by organization personnel in the processing of their information and communication needs. It encompasses the computer hardware and software, the network and several other devices, e.g audio, video, photography, camera, etc., that convert information and so on into common digital form (Yusuf, 2005). Njoku (2006) identified three categories of ICT be processed information (computer systems), disseminated information (telecommunication systems), and represented information (multi-media systems).

Information and communications Technology (ICT) has the potential to improve all aspects of our social, economic and cultural life. The role of Information and Communications Technology (ICT) in human development has received growing attention among development practitioners, policy makers, government and civil society in recent years due to the growing proliferation of the Internet, convergence in IT and telecommunications technologies and increasing globalization (N.D. Oye,2011).

The impact of new ICT has significantly changed the speed of production, use and distribution of knowledge. Time was when the principal teaching resources available to a professor were the books in the college library, his chalkboard and an occasional map on the classroom. But higher education has exhibited a trend toward a new kind of support for instructional services and an extreme development of facilities to encourage the utilization of new media (Philip Olu Jegede,2009).

\subsection{Literature Review}

K. M. Cassim, S. D. Eyono Obono, in their paper entitled "on the factors affecting the adoption of ICT for the teaching of world problems" found that, teachers' demographic profiles, their positive attitudes, their awareness of successful and effective ICT integration in teaching, and their positive perceptions on the usefulness and ease-of-use of ICT, contribute to higher levels of ICT adoption for the teaching of word problems.

Mojgan Afshari, said that The success of the implementation of ICT is not dependent on the availability or absence of one individual factor, but is determined through a dynamic process involving a set of interrelated factors. It is suggested that ongoing professional development must be provided for teachers to model the new pedagogies and tools for learning with the aim of enhancing the teaching-learning process.

Jef Peeraer (2010), investigates the factors influencing integration of ICT in teacher education in Vietnam, they found that The use of ICT applications for teaching practice is limited, mostly replacing traditional teaching practice. The factors explaining the integration of ICT in teaching practice are ICT skills and computer confidence. Significant differences exist between different teacher education institutions. Suggestions are made as to what approach to take to effectively integrate ICT in teacher education in Vietnam.

Naser Jamil AI-Zaidiyeen, found that teachers had a low level of ICT use for educational purpose, teachers hold positive attitudes towards the use of ICT, and a significant positive correlation between teachers' level of ICT use and their attitudes towards ICT was found. The findings suggest that ICTs use for educational purposes should be given greater consideration than it currently receives. In general, the results were consistent with those previously reported in studies related to the use of ICT in the educational settings

Jamieson-Proctor \& Finger (2006) found that gender has a significant relation to confidence in using ICT, by teachers for teaching. Jamieson-Proctor \& Finger ( 2006) reached this result by using the Pearson Chi-squares test of Significance to compare gender and their confidence to use ICT with their learners for teaching and learning from the survey of 929 practicing primary and secondary teachers and 285 pre-service from Queensland state schools. The survey obtained demographic data on the teacher respondents (gender, school type, years of teaching experience, confidence to use ICT with learners for teaching and learning, year levels and curriculum areas currently taught). Redmann \& Kotrlik (2009) revealed that age is significantly correlated to technology adoption, while the years of experience is not significantly correlated to technology adoption.

According to Buabeng-Andoh 2012 , Rogers (2003) argues that the process of adoption starts with initial hearing about an innovation to final adoption. For the purpose ofthis study, Rogers' definition of adoption is used. Similarly, Williams (2003) described ICT integration asthemeans of usingany ICT tools (Internet, e-learning technologies, CD ROMs, in addition some content free software etc) to assist teaching and learning. For the purpose of this study, Williams' definition of ICT integration is adopted. Several factors influencing the adoption and integration of ICT into teaching have been identified by researchers. Balanskat,et al. (2007) identified the factors as teacher-level, school-level and system-level. Teachers integration of ICT into teaching is also influenced by organizational factors, attitudes towards technology and other factors.

Kiruthika Ragupathi (2007), in his study entitled " Factors Affecting the Adoption of Information Technology (IT) in Higher Education " shows that faculty need to realise the advantage and value of using IT. Even though the infrastructure and new technologies are available, faculty will not use IT if they do not perceive any enjoyment or benefits to the teaching and learning experience. And he recommends that attempts in IT integration should focus on using technology to make a greater impact on the educational experience rather than the acquisition of infrastructure. Time and perceived benefits of using IT to develop courses will continue to be an ongoing issue. The university should think of creative approaches to ensure that faculty members have more time to experiment with integrating IT into their lessons. 


\section{METHODOLOGY}

The study has adapted the descriptive, field and analytic methods. A comprehensive survey and analyzing data that collected from questionnaires by using statistical ways were conducted to implement the field analytic research. The study based on a developed questionnaire that organized depending on the previous questionnaires; this questionnaire was adjusted to fit the Southern Colleges environment.

\subsection{Population:}

The population of this study consisted of all the Teachers of southern colleges in Balqa Applied University distributed as follows: Shoubak College ( $N=28)$, Ma'an College $(N=29)$, Aqaba College $(N=118)$, Karak College $(N=57)$ with a total of $(\mathrm{N}=232)$.

\subsection{Sample:}

The sample contains of $(80)$ teachers, as shown in the table (1.1) below. The simple random sample was selected.

Table 1. Sample of the study

\begin{tabular}{|l|l|}
\hline College & Number of respondents \\
\hline Shoubak & 10 \\
\hline Karak & 18 \\
\hline Ma'an & 10 \\
\hline Aqaba & 42 \\
\hline Total & 80 \\
\hline
\end{tabular}

\subsection{Instrument}

The questionnaire of the study was divided into three sections:

Section one: includes information about demographic variables of the sample (gender, experience, age, level of education).

Section two: includes (13) items distributed to cover familiarity and proficiency of teachers in using ICTs.

Section three: includes (8) items distributed to cover the availability of ICT to teachers.

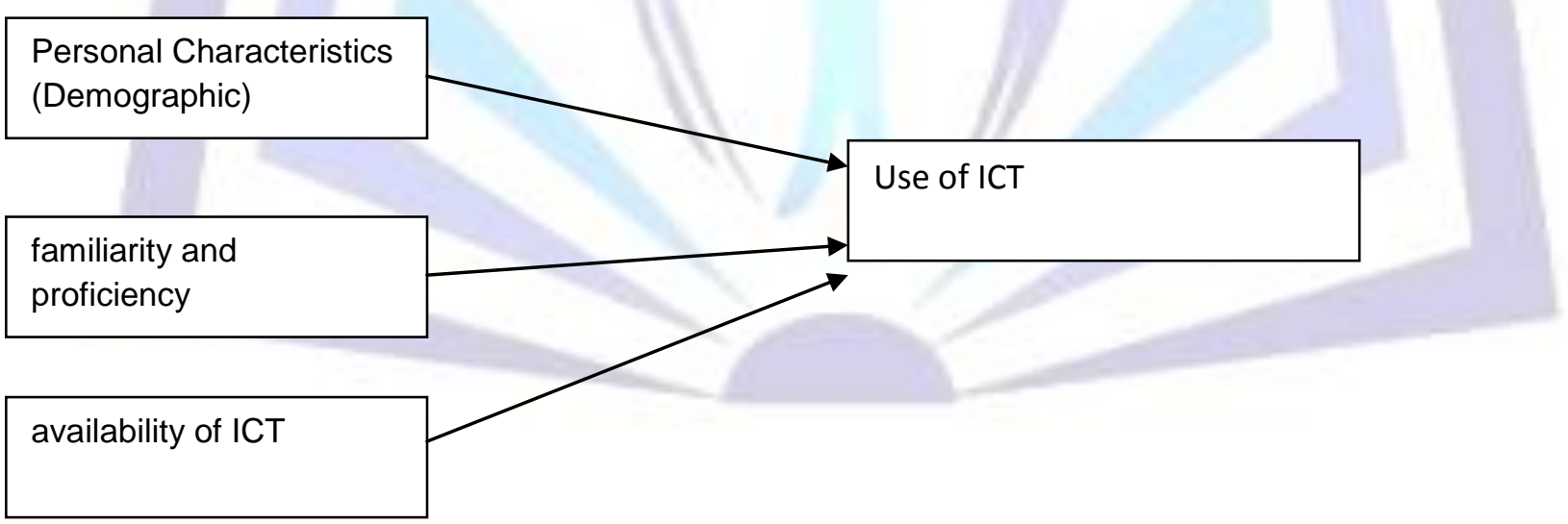

\subsubsection{Constancy of the Instrument}

Constancy factor was calculated according to (Cronbach Alpha) for internal correspondence of total formulation and for each variable with all dimensions. The questionnaire was distributed to (3) subjects outside of the sample, the results as shown in table (2).

Table 2. Value of internal correspondence for each variable (independent and dependent) with all dimensions

\begin{tabular}{|l|l|l|}
\hline Number of paragraph & Variable and dimensions & $\begin{array}{l}\text { Constancy factor } \\
\text { Cronbach Alpha }\end{array}$ \\
\hline $1-5$ & Demographic variables & 0.91 \\
\hline
\end{tabular}




\begin{tabular}{|l|l|l|}
\hline $6-18$ & Knowledge variable & 0.9 \\
\hline $19-26$ & Availability variable & 0.89 \\
\hline $1-26$ & Overall average & 0.90 \\
\hline
\end{tabular}

The table shows that constancy factors are high and valid for statistical analysis and scientific research.

\subsubsection{Statistical Process}

To answer questions about the study and test the validity of hypotheses. Descriptive Statistic Analytical methods (by using SPSS. 14) were used.

I. Descriptive Statssts Measures were used to answer the question of the study and to organize the dimensions downwardly as well as to describe the characteristics of the sample by using percentages.

II. Multible Regression Analysis was used in order to test the validity of the study and the effect of the independent variable and its dimensions in the dependent variable and its dimeminssions.

III. Analysis of test T. (One Sample Test) to test the impact of the independent variable on the dependent variable.

IV. Stepwise Multible Regression Analysis was used for using the independent variables in predicting equation of dependent variable.

V. Variance inflation Factory (VIF) and Tolerance were used for insuring that there is no high correlation between the independent variables.

VI. Skewness was used in order to insure that data follows the normal distribution.

\subsubsection{Instrument Validity}

The validity of the questionnaires was constructed by reviewing each of its questions by the supervisor and professional doctors at Balqa applied university and some Jordanian Universities.

To verify the validity of the paragraphs of questionnaires, remarkable amendments have been made to reformulate some of the paragraphs, and the required adjustments.

The results were achieved accurately to maintain a balance between the contents of questionnaires and its paragraphs.

\subsection{Discussion and findings}

The purpose of this study was to assess the Factors Affecting Information and Communication Technology (ICT) use by Southern Colleges Teachers in Balqa Applied University. Therefore, the results of this study are presented and analyzed in this section. The study used a descriptive analysis to describe the characteristics of the respondents. The research hypotheses were presented and tested, ANOVA was used to measure the differences between the sample groups, Pearson Correlation was used to explore the correlation between the study variables (dependent and independent variables).

Table 3. Description of the characteristics of a study sample

\begin{tabular}{|l|l|l|l|}
\hline gender & frequency & percent & Cumulative percent \\
\hline Female & 22 & $28 \%$ & 28 \\
\hline Male & 58 & $72 \%$ & 100 \\
\hline Total & $\mathbf{8 0}$ & $\mathbf{1 0 0 . 0}$ & \\
\hline
\end{tabular}

Table (3) indicates that $28 \%$ of the study sample are female, and the remaining (72\%) respondents male. These findings show that the most teachers in the listed colleges are from men.

Table 4. Characteristics of the respondents: Age

\begin{tabular}{|l|l|l|l|}
\hline Age & frequency & percent & Cumulative percent \\
\hline Less than 30 & 16 & $\% 20$ & 20 \\
\hline $31-45$ years & 34 & $\% 42.5$ & 62.5 \\
\hline 46-60 years & 24 & $\% 30$ & 92.5 \\
\hline More than 60 & 6 & $\% 7.5$ & 100.0 \\
\hline
\end{tabular}




\begin{tabular}{|l|l|l|l|}
\hline total & 80 & 100.0 & \\
\hline
\end{tabular}

Table (4) shows that $20 \%$ of the study sample is less than 30 years, $42.5 \%$ is between $31-45$ year, $30 \%$ is between $46-60$ year, and $7.5 \%$ older than 60 years. The findings of this table show that few of the respondents were from the $4^{\text {th }}$ level and the majority of the respondents lie in the $2^{\text {nd }}$ level.

Table 5. Characteristics of the respondents: Education level

\begin{tabular}{|l|l|l|l|}
\hline Education level & frequency & percent & Cumulative percent \\
\hline 4 years college & 10 & $12.5 \%$ & 12.5 \\
\hline Master & 32 & $40 \%$ & 52.5 \\
\hline Doctorate & 38 & $47.5 \%$ & 100.0 \\
\hline Total & $\mathbf{8 0}$ & $\mathbf{1 0 0 . 0}$ & \\
\hline
\end{tabular}

Table (5) indicates that $12.5 \%$ of the study sample from 4 years college, $40 \%$ Master Degree, and $47.5 \%$ from Doctorate degree. The findings show that the most respondents were from Doctorate Degree and this means that most of the teachers have a high level of education.

Table 6. Characteristics of the respondents: Experience

\begin{tabular}{|l|l|l|l|}
\hline Experience & frequency & percent & Cumulative percent \\
\hline Less than 2 years & 3 & $4 \%$ & 4 \\
\hline 3-6 years & 5 & $6 \%$ & 10 \\
\hline 7-10 years & 50 & $63 \%$ & 73 \\
\hline More than 10 years & 22 & $27 \%$ & 100.0 \\
\hline Total & $\mathbf{8 0}$ & $\mathbf{1 0 0 . 0}$ & \\
\hline
\end{tabular}

Table (6) clarifies that $4 \%$ of the respondents whom have less than two years experience, $6 \%$ whom have an experience between 3-6 years, $63 \%$ whom have an experience between $7-10$ years, and $27 \%$ whom have an experience more than 10 years. The findings showed that the least respondents are from the 1st level, and the majority of the respondents whose years of experience lay between seven and ten.

The following are the results of statistical analysis of the data, relying on analysis of T test. (One Sample Test) to test the impact of the independent variable on the dependent variable is the value of mathematical averages and standard deviations, and arranged to study all dimensions, and paragraphs after each component, taking into account the measure to include user In the study as follows:

\begin{tabular}{|l|l|l|l|l|}
\hline strongly Disagree & Disagree & Undecided & Agree & Strongly Agree \\
\hline 1 & 2 & 3 & 4 & 5 \\
\hline
\end{tabular}

H1: personal characteristics positively affect the use of ICT in Southern colleges of Blaqa Applied University.

Table 6. Analysis of test results $\mathrm{T}$ (One Sample Test) to test the impact of personal characteristics positively affect the use of ICT in Southern colleges of Blaqa Applied University

\begin{tabular}{|l|l|l|l|l|l|l|}
\hline Factors & Mean & Std & rank & Severity & T.Value & Sig \\
\hline gender & 3.62 & 0.47 & 3 & high & $29.73^{*}$ & 0.000 \\
\hline age & 3.61 & 0.5 & 4 & high & $24.28^{*}$ & 0.000 \\
\hline experience & 3.67 & 0.54 & 1 & high & $21.53^{*}$ & 0.000 \\
\hline Education level & 3.64 & 0.51 & 2 & high & $20.11^{*}$ & 0.000 \\
\hline Overall average & $\mathbf{3 . 6 3}$ & $\mathbf{0 . 5 0}$ & - & high & $\mathbf{2 3 . 9 1}^{\text {* }}$ & $\mathbf{0 . 0 0 0}$ \\
\hline
\end{tabular}

${ }^{*}$ Statistically significant level $(\leq 0.05) \alpha$ 
It can be seen from Table (6) that the overall average impact of personal characteristics on the use of ICT in Southern colleges of Blaqa Applied University is high (3.63), the standard deviation (0.5), which indicates that the impact of personal characteristics of teachs in using ICT has been ranked of a high degree, and occupied dimension (experience) ranked first average(3.67), followed by dimension (education level) with average (3.64), dimension (gender) with average (3.62) occupied 3rd place. and finally the age dimension occupied average (3.61). As such, all values of (t) were calculated at the level of $(\alpha \geq 0.5$, therefore we reject the null hypothesis and accept the alternative hypothesis, which provides personal characteristics positively affect the use of ICT in Southern colleges of Blaqa Applied University.

$\mathrm{H} 2$ : familiarity and proficiency of teachers positively affect the use of ICT in Southern colleges of Blaqa Applied University.

Table 7. Analysis of test results T. (One Sample Test) to test the impact of familiarity and proficiency of teachers on using ICT in Southern colleges of Blaqa Applied University

\begin{tabular}{|l|l|l|l|l|l|l|}
\hline Factors & Mean & Std & rank & Severity & T.Value & Sig \\
\hline Computers & 3.62 & 0.51 & 4 & high & $* 19.777$ & 0.000 \\
\hline Datashow & 3.57 & 0.50 & 5 & high & $17.961 *$ & 0.000 \\
\hline CD/DVD & 3.56 & 0.58 & 6 & high & $15.898 *$ & 0.000 \\
\hline Internet & 3.65 & 0.60 & 2 & high & $17.531 *$ & 0.000 \\
\hline Education Slides & 3.71 & 0.59 & 1 & high & $19.172 *$ & 0.000 \\
\hline Online Materials & 3.64 & 0.55 & 3 & high & $17.866 *$ & 0.000 \\
\hline Overall average & $\mathbf{3 . 6 2}$ & $\mathbf{0 . 4 7}$ & - & high & *29.73 & $\mathbf{0 . 0 0 0}$ \\
\hline
\end{tabular}

* Statistically significant level $(\leq 0.05) \alpha$

The above table elucidates that the overall average impact of familiarity and proficiency of teachers in using ICT in Southern colleges of Blaqa Applied University is high, it reached (3.62), the standard deviation (0.47), which indicates that the impact familiarity and proficiency of teachers in using ICT in Southern colleges of Blaqa Applied University and it has got a high degree, so, the first dimension (educational slides) occupied first rank with average(3.71), followed by dimension (internet) with average (3.65), dimension (online materials) came in third with average (3.64), the dimension (computers) came in fourth place with average (3.62), while the dimension (datashow) was ranked fifth with average (3.57). Finally dimension (CD/DVD) came in last rank with average (3.56). Thus, the researchers has noticed that all values of $(t)$ were calculated at the level of $(\alpha \geq 0.05)$, and therefore we reject the null hypothesis and accept the alternative hypothesis, which provides that familiarity and proficiency of teachers influences positively on the use of ICT in Southern colleges of Blaqa Applied University.

H3 : availability positively affect the use of ICT in Southern colleges of Blaqa Applied University.

Table 8. Analysis of test results T. (One Sample Test) to test the availability effect on the use of ICT in Southern colleges of Blaqa Applied University

\begin{tabular}{|l|l|l|l|l|l|l|}
\hline Factors & Mean & Std & rank & Severity & T.Value & Sig \\
\hline Internet & 3.61 & 0.65 & 3 & high & $15.174^{*}$ & 0.000 \\
\hline Datashow & 3.60 & 0.64 & 4 & high & $13.438^{*}$ & 0.000 \\
\hline Computers & 3.69 & 0.52 & 1 & high & $23.828^{*}$ & 0.000 \\
\hline CD/DVD & 3.57 & 0.65 & 6 & high & $14.482^{*}$ & 0.000 \\
\hline Education Slides & 3.63 & 0.57 & 2 & high & $14.679^{*}$ & 0.000 \\
\hline Online Materials & 3.58 & 0.66 & 5 & high & $12.853^{*}$ & 0.000 \\
\hline Overall average & $\mathbf{3 . 6 1}$ & $\mathbf{0 . 5 0}$ & - & & $\mathbf{*}^{*} \mathbf{2 4 . 2 8}$ & \\
\hline
\end{tabular}

* Statistically significant level $(\leq 0.05) \alpha$

Table (8) elucidates that the overall average impact of availability of ICT on the use of ICT by Southern College teachers is high (3.61), the standard deviation (0.50). It indicates that the impact of availability of ICT have been of a high degree. Many respondents agreed with the statement that (computers) is a possible reason which might have motivated teachers to use ICT. It occupied first rank with average (3.69), followed by dimension (educational slides) with average (3.63), dimension (internet) came in third with average (3.61), while dimension (Datashow) was the fourth rank with average (3.60), although the respondents agreed with the dimension (online materials) came in the fifth place with average (3.58). Finally dimension (CD/DVD) came in the last rank with average (3.57). The researchers in this study has 
opined that all values of $(t)$ were calculated at the level of $(\alpha \geq 0.05)$. Therefore we reject the null hypothesis and accept the alternative hypothesis which provides availability positively affect the use of ICT in Southern colleges of Blaqa Applied University

\section{CONCLUSION}

Integration of ICT in higher education is inevitable. In the coming years the thrust will be on the use of ICT to strengthen the system in the mode of opens and distance learning. Institutional and sector-wide higher education ICT policy and planning should identify the specific role of ICT in enhancing research capabilities and provide for adequate infrastructure. [Ulka Toro,2012]

The results of this study indicate that even though a majority of respondents use ICT in teaching activities. The descriptive results indicated that teachers had high level of knowledge and skill in applying ICT. In addition, computer and internet are available to majority of respondents. It appeared from the findings of this research that technologies are used at the high level. Providing more availability of ICT to teachers as the most producers of the information and knowledge will be essential. The findings of regression analysis also showed that the skill in using ICT explained 3.63 of extent to which faculty members used ICT variance. This result refers to the fact that holding educational courses aiming at increasing people's familiarity and knowledge about ICT will improve the usage of these technologies.

\section{RECOMMENDATIONS AND FUTURE WORK}

The findings of this study may be of practical importance to those academic, community-based organizations whose purpose is to provide higher education who increasingly find themselves beleaguered by global competition, would be well served by becoming informed and educated about the powerful cost-effective capabilities of using ICT in teaching.

Technology costs, including hardware and software, are declining and becoming affordable and available for higher education institutions. However, for an effective learning process to be forged, current educational practices must be examined before the technology tools are put in place, or ineffective processes simply become mechanized.

\section{REFERENCES}

[1]. Yusuf, M. O. (2005). Integrating information and communication technologies in Nigerian tertiary education. The African Symposium, 5(2), 2005: An On-line Educational Research Journal: A Publication of the African Education Research Network. http://www2.ncsu.edu/ncsu/aern/INDEX.HTML.

[2]. Njoku, S. (2006). ICT and Nigerian teachers. Paper delivered at Teachers' Registration Council of Nigeria (TRCN) National Workshop. Abuja: TRCN.

[3]. N.D.Oye et al, International Journal of Computer Science \& Communication Networks, Vol 1(1), SeptemberOctober 2011

[4]. Philip Olu Jegede, Assessment of Nigerian Teacher Educators' ICT Training. Issues in Informing Science \& Information Technology. 2009, Vol. 6, p415-420

[5]. K. M. Cassim, S. D. Eyono Obono, on the factors affecting the adoption of ICT for the teaching of world problem, Proceedings of the World Congress on Engineering and Computer Science 2011 Vol I WCECS 2011, October 19-21, 2011, San Francisco, USA

[6]. Mojgan Afshari, Kamariah Abu Bakar, Wong Su Luan, Bahaman Abu Samah \& Foo Say Fooi, factors affecting teachers' use of information and communication technology, International Journal of Instruction January 2009 ,Vol.2, No.1

[7]. Jef Peeraer, Factors Influencing Integration of ICT in Higher Education in Vietnam, Global Learn, May 17, 2010 in Penang, Malaysia Publisher: AACE

[8]. Naser Jamil Al-Zaidiyeen, Leong Lai Mei, Fong Soon Fook, Teachers' Attitudes and Levels of Technology Use in Classrooms:The Case of Jordan Schools, International Education Studies Vol. 3, No. 2; May 2010

[9]. Romina M. Jamieson-Proctor, Paul C. Burnett, Glenn Finger and Glenice Watson, ICT integration and teachers' confidence in using ICT for teaching and learning in Queensland state schools, Australasian Journal of Educational 2006, 22(4), 511-530

Technology

[10].Buabeng-Andoh, Charles, Factors influencing teachers' adoption and integration of information and communication technology into teaching: A review of the literature, International Journal of Education \& Development using Information \& Communication Technology. 2012, Vol. 8 Issue 1, p136-155

[11]. Kiruthika Ragupathi , Krishna Booluck, Rita Roop , Factors Affecting the Adoption of Information Technology (IT) in Higher Education CDTL Brief / April 2007, Page 7 